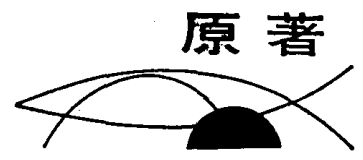

\title{
自動尿糖測定便器の試作機 に関する基礎的検討および実用試験
}

\author{
伊 藤 克 己* 本 多 憲 児*2 \\ 齋 藤 史 朗*3
}

\author{
Evaluation of Basic Performance and Utility of \\ The Automated Stool for Quantitative Determination \\ of Glucose in Urine \\ Katsumi ITO, M.D. \\ Pediatric Nephrology Kidney Center, \\ Tokyo Women's Medical College \\ 8-1 Karvada-cho, Shinjuku-ku, Tokyo, 162, Japan
}

Kenji HONDA, M.D.

Honda Memorial Tohoku Cardio-Vascular Medical Center 3-4-1 Namiki, Koriyama, Fukushima, 963, Japan

Shiro SATTO

Development Department, INAX Corporation

3-77 Minatomachi, Tokoname, Aichi, 479, Japan

\begin{abstract}
An automated Stool (western style) was developed for daily Quantitative Determination of Glucose in Urine. Glucose is determined by measurement of dissolved oxygen with GOD and the oxygen electrode of measurement mechanism set in the stool. The result of examination of the basic performance showes us a value for determination of Glucose in Urine.

The stool was tested on 152 patient at a hospital closet. The Diabetes Mellitus was detected by the stool, and a simple operation enables repeated examination. This article reports the result of the examination of basic performance and the utility.
\end{abstract}

\section{1.はじめに}

食事の欧風化に象徵される美食, 過食に伴い 糖尿病患者は増加の一途である.他の疾病と同

* 東京女子医科大学腎臟病総合医療センター小览科

$* 2$ 本多記念東北循環器科病院

*8 㑣 INAX 商品開発本部

(原稿受付 : 平成元年 5 月 24 日)
様に糖尿病も初期治療の重要性は言を待たない。 糖尿病の発見には尿糖試験紙などによるスクリ ーニング検查が有効である.ところがこれまで の検查では, (1)尿をわざわざ便室から検查室へ 持ち込む，(2)検查後の尿の後始末が必要, (3)使 用済の試験紙の衛生的な廃棄, などのわずらわ しさがあった。このような事情から便器そのも のに測定機能を有するものが望まれていた．今 
回, 自動尿糖測定便器 (XDC-86 SK, 跦 INAX 製）の試作品の基本的性能，実用性について検 討を加えたので，その結果を報告する.

\section{2. 装置の概要}

\section{2-1. 測定原理}

グルコースは，グルコース試薬 (Mutarotase, Glucose Oxidase，天野製薬(侏製) を用い，そ の酵素反応による溶存酸素消費速度を溶存酸素 電極で測定することによって検出する ${ }^{1}$.

尿とグルコース試薬とが混合されると酵素反 応が起り，15 50秒後に酸素消費速度が最大值 となる.この最大值は尿中のグルコース量に比 例する. 反応槽（採尿器）に設置された溶存酸 素電極の信号を微分し，その最大值を得ること によりグルコース量を測定表示する.

グルコースの酵素反応は次のように進行する. $\alpha-\mathrm{D}$-Glucose $\stackrel{\text { MUT }}{\longrightarrow} \beta$-D-Glucose $\beta-\mathrm{D}$-Glucose $+\mathrm{O}_{2}+\mathrm{H}_{2} \mathrm{O} \stackrel{\mathrm{GOD}}{\longrightarrow} \longrightarrow$

D-Clucono- $\delta$-lactone $+\mathrm{H}_{2} \mathrm{O}_{2}$ *MUT : ムタロターゼ (Mutarotase)

GOD：グルコースオキシダーゼ

(Glucose Oxidase)

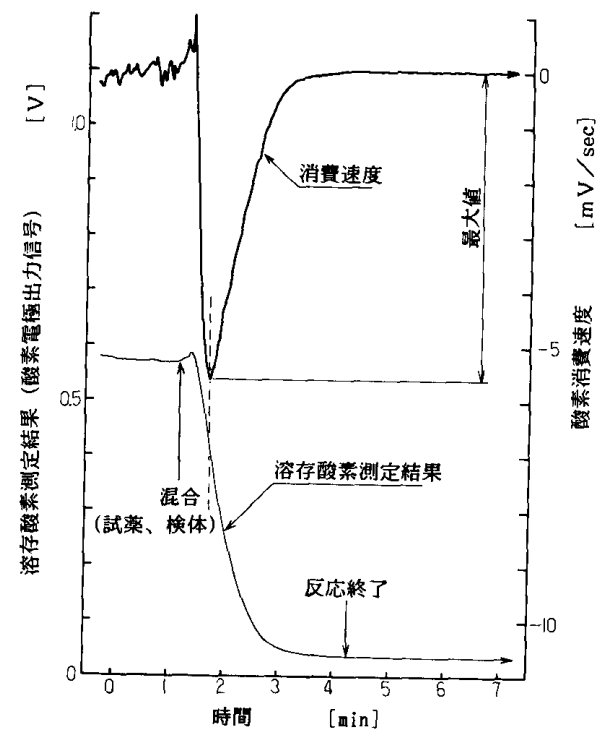

図 1 測定原理図 (Glucose $100[\mathrm{mg} / \mathrm{d} l]$ )

\section{2-2. 装置の構成}

本装置は男女兼用を考慮し洋風便器をべース に構成されている.測定動作は自動でなされ， 専門的な知識を必要とせず，だれにでも簡単に

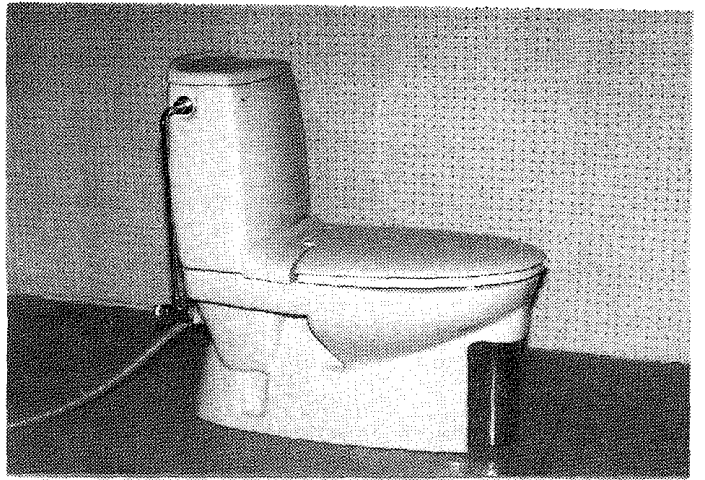

図 2 XDC-86SK 外観

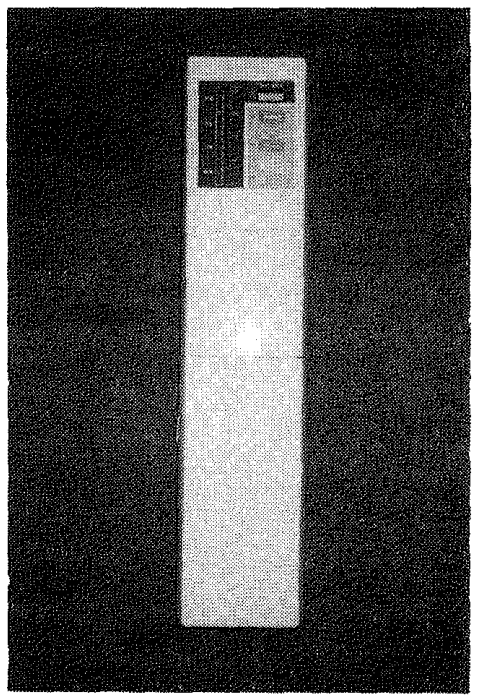

図 3 操作・表示部

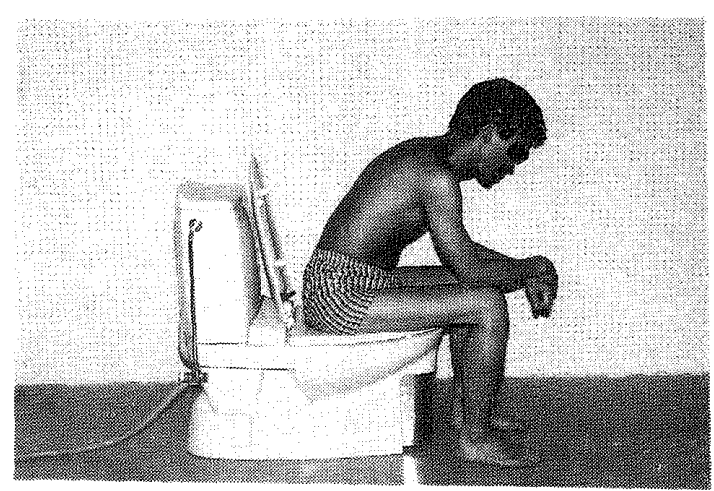

図 4 使用状態

使用できる，試薬はカートリッジ方式によって ワンタッチで簡単に補給できる。測定精度注定 期的な標準液による較正で維持される.

本装置は，操作・表示部，酸素電極を備えた 反応槽兼採尿器, 希䣋水・試薬分注機構，抢上 び洋風便器によって構成されている. 一連の測 定動作はマイクロコンピュータによって制御さ れ，次のように行われる。

(1) 便鉢内の尿当り部のピストンが下り，採尿 器が形成される. 


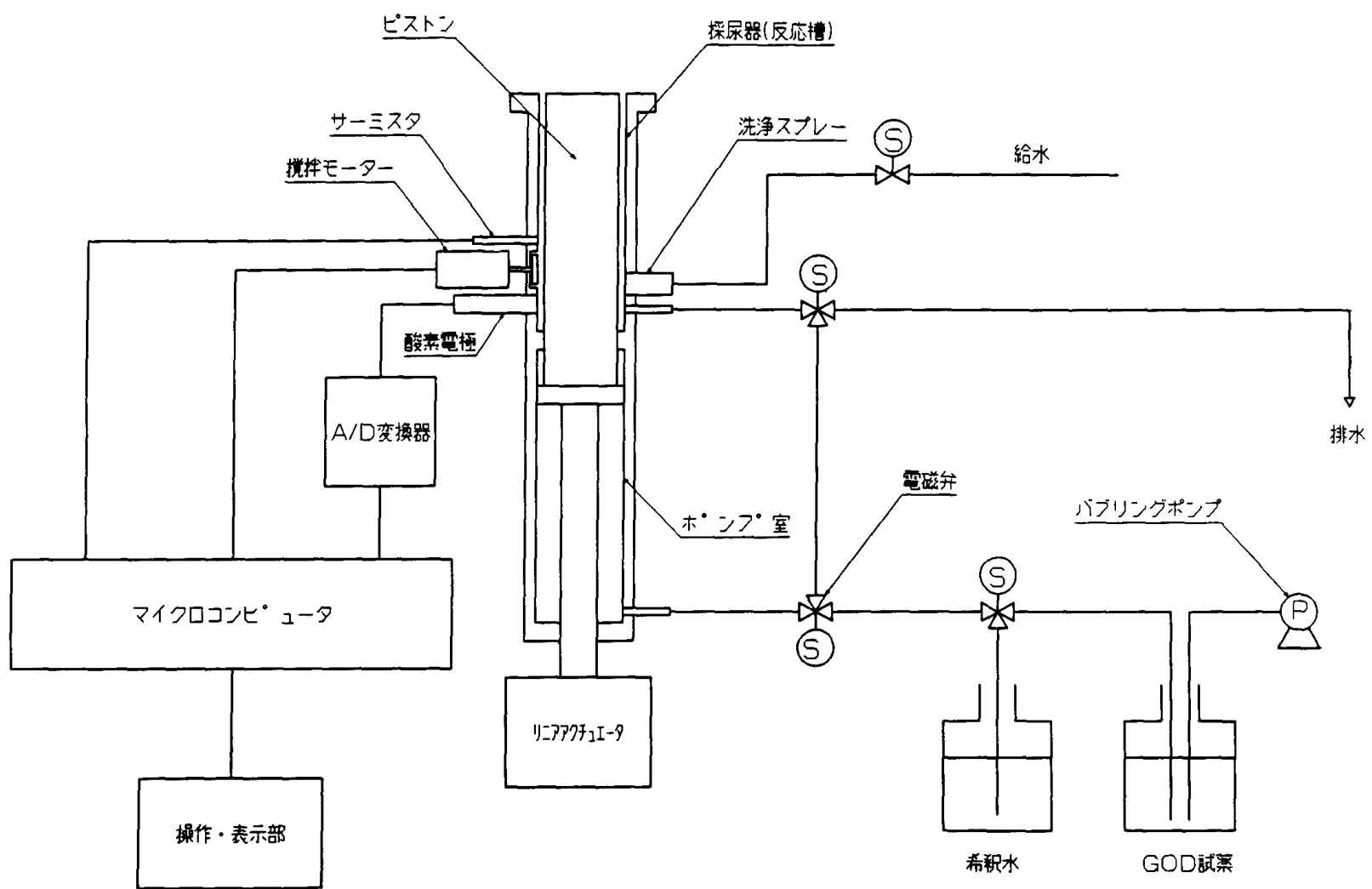

図 5 シ ス テ

(2) 被験者が放尿する.

(3) ピストンの上下，およびそれに連動したポ ンプの動作によって尿を希釈する。

(4) 希釈尿と酵素試薬を混合する.

(5) 㽷と試薬の反応が開始する.

(6) 酸素電極で酵素反応による最大酸素消費速 度を検出しマイクロコンピュータによって換 算されたグルコース濃度を表示する。

(7) ピストンの上下，および洗浄スプレーによ って採尿器, ポンプ部を洗浄し初期状態に戻 る。

\section{2-3. 仕 様}

1. 測定方式：グルコースオキシダーゼ試薬 ——酸素電極法

2. 測定対象：尿中グルコース

3. 測定範囲 : $0 \sim 300[\mathrm{mg} / \mathrm{d} l]$

4. 結果表示: LED バーグラフ（表示範囲 $0 \sim 200[\mathrm{mg} / \mathrm{d} l])$ テストモードによって LED 数字 3 桁 (0〜999 表示)

5. 採取検体量 : $7[\mathrm{ml}]$

6. 処理時間 : 約 3 [分]

7. 試薬補給：カートリッジ式(容量 $330[\mathrm{ml}]$,
測定60回分）

8. 使用時周囲温度 : $15 \sim 30\left[{ }^{\circ} \mathrm{C}\right]$

9. 通信インターフェース : RS-232 C

10. 便 器: 給水 $\cdots$ ロータンク式

$$
\begin{aligned}
& \text { 洗浄…サイホン式 } \\
& \text { 使用水量…11 [l] }
\end{aligned}
$$

11. 基本構成：操作 - 表示部, 分析部分離型

12. 電 源: AC $100[\mathrm{~V}], 50 / 60[\mathrm{~Hz}]$

13. 重 量: 約 60 [kg]

14. 寸 法 : 操作表示部…150W $\times 80 \mathrm{D} \times 650 \mathrm{H}$ 便 器 $\cdots 370 \mathrm{~W} \times 765 \mathrm{D} \times 785 \mathrm{H}$

\section{3. 基礎的試験}

\section{3-1. 特異性試験}

管理尿 (Quantimetrix Urine Control, Level 1. Glucose $46 \pm 5[\mathrm{mg} / \mathrm{d} l]$ (ASTRA)) 3 種 について特暴性試験を行ったが，いずれもほ ぼ同等の值 $49,45,45[\mathrm{mg} / \mathrm{d} l]$ を示し，混入 Glucose 量とほぼ同量であり，Glucose に対し 特異的に反忘することが認められた。

\section{3-2. 再現性試験}

a. 日差再現性 
表 1 日 差 再 現 性

単位 : $[\mathrm{mg} / \mathrm{d} l]$

\begin{tabular}{|cc|c|c|c|c|c|c|c|c|c|c|c|c|c|}
\hline 日 & 数 & 1 & 2 & 3 & 4 & 5 & 6 & 7 & 8 & 9 & 10 & 平 均 & $\sigma_{\mathrm{n}-1}$ & $\mathrm{CV}[\%]$ \\
\hline 尿 & (1) & 0 & 0 & 0 & 0 & 0 & 0 & 0 & 0 & 3 & 0 & 0.3 & - & - \\
\hline 尿 (2) & 51 & 45 & 42 & 46 & 52 & 51 & 57 & 51 & 50 & 58 & 50.3 & 4.99 & 9.92 \\
\hline 尿 (3) & 96 & 98 & 94 & 96 & 89 & 96 & 90 & 93 & 106 & 101 & 95.9 & 5.02 & 5.24 \\
\hline 尿 (4) & 148 & 145 & 157 & 143 & 145 & 153 & 151 & 143 & 144 & 145 & 147.4 & 4.77 & 3.23 \\
\hline
\end{tabular}

表 2 同 時 再 現 性 単位 : $[\mathrm{mg} / \mathrm{d} l]$

\begin{tabular}{|cc|c|c|c|c|c|c|c|c|c|c|c|c|c|}
\hline 回 & 数 & 1 & 2 & 3 & 4 & 5 & 6 & 7 & 8 & 9 & 10 & 平 均 & $\sigma_{\mathrm{n}-1}$ & CV[\%] \\
\hline 尿 & (1) & 0 & 0 & 0 & 0 & 0 & 0 & 0 & 0 & 0 & 0 & 0 & - & - \\
\hline 尿 & (2) & 56 & 54 & 54 & 56 & 56 & 49 & 59 & 51 & 53 & 49 & 53.7 & 3.27 & 6.09 \\
\hline 尿 (3) & 105 & 108 & 109 & 102 & 107 & 97 & 101 & 98 & 98 & 98 & 102.3 & 4.62 & 4.52 \\
\hline 尿 (4) & 146 & 141 & 148 & 146 & 141 & 148 & 145 & 148 & 156 & 156 & 147.5 & 5.17 & 3.50 \\
\hline
\end{tabular}

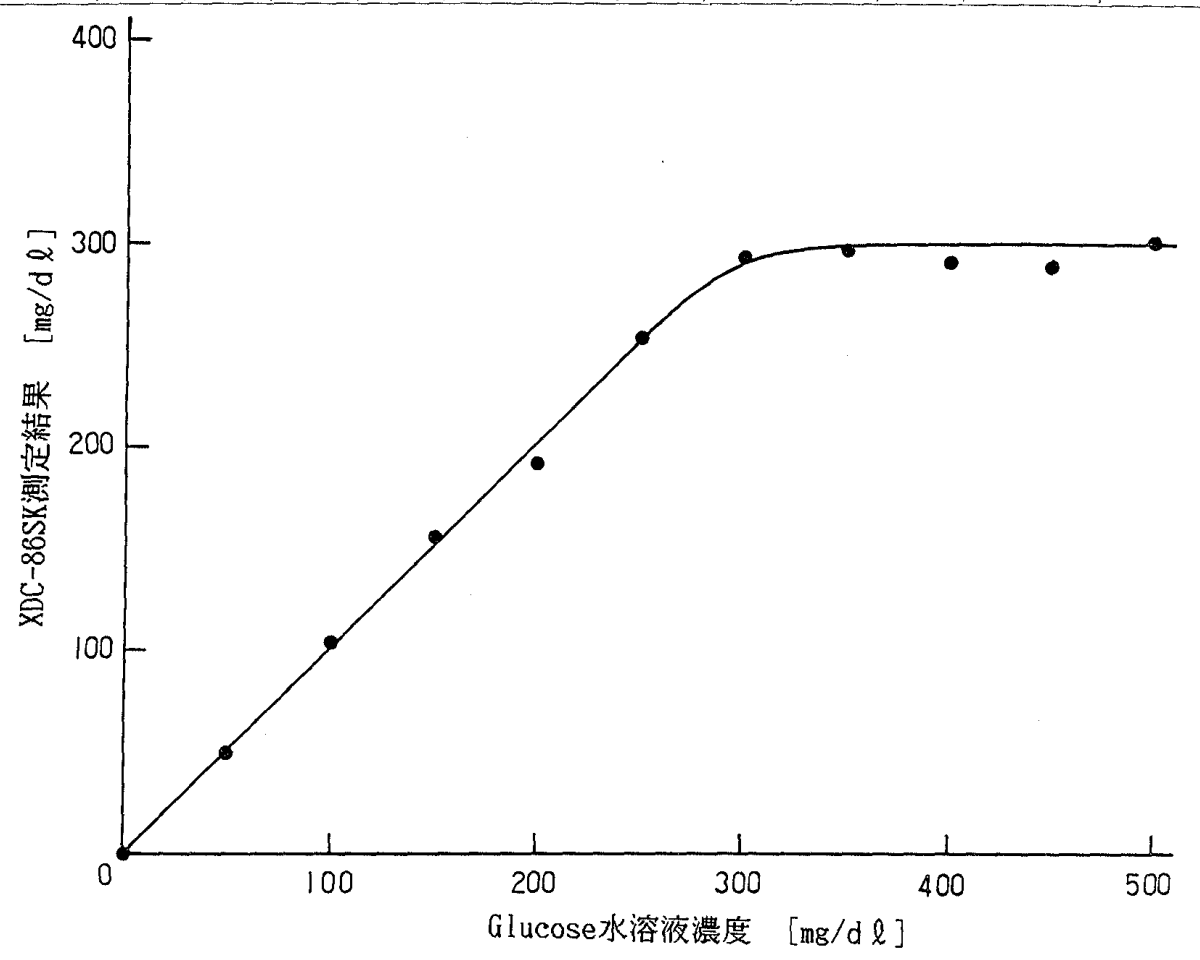

図 6 直

線

尿糖陰性尿 1 例（尿(1)），尿楉陽性尿 3 例（尿 (2)，(3)，(4)）について同一尿を10日間毎日尿糖 測定したところ，10日にわたり毎日の測定値に は著しい相異は見られなかった。

b. 同時再現性

前記 4 例の尿について同時に10回測定を行っ ても，いずれもほとんど同様の測定值を示し， 著しい測定䛊差は認められなかった。

\section{3-3. 直線 性}

Glucose を混入した各濃度の水溶液を測定し
たところ，約 $300[\mathrm{mg} / \mathrm{d} l]$ までは直線を示し たが，それ以上の測定は不可能であった。この ことから尿糖 $300[\mathrm{mg} / \mathrm{d} l]$ 以上の時には测定 不能『over』とした。

\section{3-4. 共存物質の影響}

健康者尿 $100[\mathrm{~m} l]$ 当り $100[\mathrm{mg}]$ の Gluose を添加し標準㽷とした，共存物質として各種の 糖 13 種類の $300[\mathrm{mg} / \mathrm{d} l]$ 水溶液, システイン $300[\mathrm{mg} / \mathrm{d} l]$ 水溶液，アスコルビン酸 $3[\mathrm{~g} / \mathrm{dl}]$ 水溶液，およびビリルビン $12.4[\mathrm{mg} / \mathrm{d} l]$ 水溶 
表 3 共存物質の影響

\begin{tabular}{|c|c|c|c|c|c|}
\hline No. & 添加 量 $[\mathrm{mg} / \mathrm{d} l]$ & 9 & 15 & 21 & 30 \\
\hline 1 & マルトース & 0 & 0 & 0 & O \\
\hline 2 & マルトトリオース & 0 & $\bigcirc$ & $\bigcirc$ & 0 \\
\hline 3 & D-フルクトース & 0 & 0 & 0 & 0 \\
\hline 4 & ガラクトース & 0 & 0 & 0 & 0 \\
\hline 5 & マンニトール & $\bigcirc$ & 0 & 0 & 0 \\
\hline 6 & イノシトール & 0 & $\bigcirc$ & 0 & 0 \\
\hline 7 & キシロース & 0 & 0 & 0 & 0 \\
\hline 8 & L-ソルボース & 0 & O & 0 & 0 \\
\hline 9 & L-ラムノース & 0 & 0 & 0 & 0 \\
\hline 10 & ラフィノース & O & 0 & 0 & 0 \\
\hline 11 & D-アラビノース & 0 & 0 & 0 & 0. \\
\hline 12 & Dーセロビオース & 0 & 0 & 0 & 0 \\
\hline 13 & サッカロース & 0 & 0 & 0 & 0 \\
\hline \multirow[t]{2}{*}{14} & L-システイン & 0 & 0 & 0 & 0 \\
\hline & 添加量 $[\mathrm{mg} / \mathrm{d} l]$ & 90 & 150 & 210 & 300 \\
\hline \multirow[t]{2}{*}{15} & アスコルビン酸 & 0 & 0 & 0 & 0 \\
\hline & 添加量 $[\mathrm{mg} / \mathrm{d} l]$ & 0.62 & 1.24 & & \\
\hline 16 & ビリルビン & 0 & 0 & & \\
\hline
\end{tabular}

○：影響なし

液を調製し，さらにこれらの $3 / 10 ， 1 / 2 ， 7 / 10$ 濃度の水溶液を作成した。これらの各種水溶液 と標準尿とを 1:9 の割合で混合したものを共 存試料とし，測定した成績では，いずれもほぼ 同様の測定值を示し，共存物質による影響は見 られなかった。

\section{3-5. 他法との相関}

被験尿 57 例について本法 (y) と, Glucose Dehydrogenase 法 (x) (Glu 試薬 A. 国際試 薬, 自動分析装置 TBA-480 東芝）による測定 値を比較した。

相関倸数 $r=0.971$, 回帰直線

$y=0.923 \mathrm{X}+7.405$ との結果を得，自動分析 装置による測定値と著しい相巽の無いことが認 められた。

\section{3-6. 添加回収}

添加 Glucose の回收率は 90 103 [\%] (平

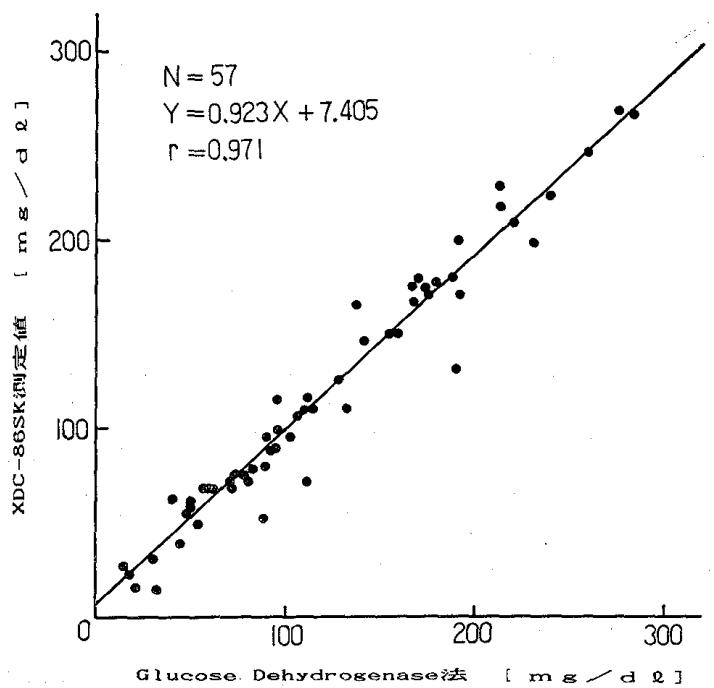

図 7 他法との相関

均 $97.7[\%]$ ) で, 添加 Glucose がほぼ同量 回収された。 
表 4 添 加回 収

\begin{tabular}{|l|r|r|r|r|}
\hline 添 加 量 $[\mathrm{mg} / \mathrm{d} l]$ & 0 & 30 & 60 & 90 \\
\hline 測 定 值 $[\mathrm{mg} / \mathrm{d} l]$ & 63 & 90 & 125 & 153 \\
\hline 回 収 量 $[\mathrm{mg} / \mathrm{d} l]$ & - & 27 & 62 & 90 \\
\hline 回 収 率 $[\%]$ & - & 90 & 103 & 100 \\
\hline 平均回収率 $[\%]$ & \multicolumn{3}{|c|}{97.7} \\
\hline
\end{tabular}

\section{4. 実用試験について}

\section{4-1. 実験場所，期間，および試験}

以上の基礎的検討結果を受けて，本多記念東 北循環器科病院に本装置を設置し, 実用性を評 洒した。試験期間は 63.7.11 から 63.9.8 まで の約 2 力月とした.

別法として尿糖試験紙（プレテスト, 和光純 薬）を使用し，本装置の結果と対比させ，合わ せて血糖值を記録した。

\section{4-2. 被 験 者}

被験者は当病院の入院, および外来患者とし た. 主として糖負荷試験実施時に合わせて行っ た.

表 5 被験者の層別単位 : [人]

\begin{tabular}{|c|c|c|}
\hline 年 歯層 & 男 $(M)$ & 女 $(F)$ \\
\hline 20 代 & 1 & 3 \\
\hline 30 代 & 2 & 1 \\
\hline 40 代 & 7 & 3 \\
\hline 50 代 & 20 \\
\hline 60 代 & 22 \\
\hline 70 代 & 16 \\
\hline 80 代以上 & 27 \\
\hline 小 計 & 71 \\
\hline 合 計 & 152 \\
\hline
\end{tabular}

\section{4-3. 他方との対比}

試験紙，本法陽性は24例（15.8\%）であり， 試験紙陰性，本法陽性注26例 (17.1\%) で，い ずれも糖尿病の診断が下だされていた。試験紙, 本法いずれも陰性例は健康人であった。

\section{4-4. 血糖值との関係}

血糖值 $150[\mathrm{mg} / \mathrm{d} l]$ 以上の糖尿病患者 34 例 は総て, 本法陽性であり，このうち11例 $(32 \%)$ は試験紙陰性であった。血糖值 $130 \sim 149$ [mg/ $\mathrm{d} l]$ の19例のうち10例 (52\%) は試験紙, 本法 共に陰性，9例 (48\%) は本法陽性であった。

血糖值 $129[\mathrm{mg} / \mathrm{d} l]$ 以下の 99 例中92例 $(93 \%)$ はいずれも本法, 試験紙ともに陰性，7例は本 法 49 [mg/d l] であった。これら99例は糖尿 病の診断はつけられていなかった.

要約すると糖尿病と診断された50例中, 本法 陽性は43例（86\%)，陰性 7 例（14\%）であり， 糖尿病診断の付されなかった 102 例では本法陽 性 7 例 $(6.8 \%)$ のみであった.

\section{5. 考 察}

糖尿病は比較的頻度の高い疾患であり，かつ 種々の重症合併症を伴うのでその早期発見は非 常に重要な研究課題である. 患者は一般に愁訴 が少ないか，ほとんど無いので，診断が遅れが ちである。

著者らは，日常排尿時にその場で尿糖検查が 出来ないかと考え, 共同で自動尿糖測定便器を 開発し，その完了をみたので，その有用性につ いて検討し成績を述べた。

特異性, 再現性, 直線性, 共存物質の影響, 他法との相関, および添加回収などの基本性能 として，良好な結果が得られた，特に酵素試薬， 溶存酸素電極を用いることにより，アスコルビ ン酸, ビリルビンなどの, 還元物質をはじめと する共存物質の影響を受けない。これらの基礎

表 6 糖尿のスクリーニング（尿糖試験紙との対比）

\begin{tabular}{|c|r|r|r|}
\hline 試験紙検出, かつ便器検出 & 24 例 & $15.8[\%]$ & $32.9[\%]$ \\
\hline 試験紙不検出, 便器検出 & 26 例 & $17.1[\%]$ & \\
\hline 試験紙, 便器双方不検出 & 102 例 & & $67.1[\%]$ \\
\hline 合 計 & 152 例 & & $100[\%]$ \\
\hline
\end{tabular}


表 7 血糖值との関係

単位；[例]

\begin{tabular}{|c|c|c|c|c|c|c|}
\hline & \multicolumn{5}{|c|}{ 尿 糖 值 (本装置測定) $[\mathrm{mg} / \mathrm{d} l]$} \\
\hline & & 陰 性 & $\sim 49$ & $50 \sim 99$ & $100 \sim$ & 計 \\
\hline \multirow{2}{*}{ 血 } & $200 \sim$ & 0 & 0 & $\begin{array}{l}1 \\
(\bigcirc)\end{array}$ & $\begin{array}{l}12 \\
\text { (全例 ) }\end{array}$ & 13 \\
\hline & $150 \sim 200$ & 0 & $\begin{array}{l}2 \\
(\text { 全例 } \bigcirc)\end{array}$ & $\begin{array}{l}12 \\
(4 \text { 例O) } \\
(8 \text { 例 } \bigcirc)\end{array}$ & $\begin{array}{l}7 \\
\text { (全例○) }\end{array}$ & 21 \\
\hline 糖 & $130 \sim 149$ & $\begin{array}{l}10 \\
(\text { 全例 } \bigcirc)\end{array}$ & $\begin{array}{l}2 \\
\text { (全例○) }\end{array}$ & $\begin{array}{l}4 \\
\text { (全例 ○) }\end{array}$ & $\begin{array}{l}3 \\
(2 \text { 例 } \bigcirc) \\
(1 \text { 例 })\end{array}$ & 19 \\
\hline \multirow{3}{*}[\mathrm{mg}/\mathrm{d}l]{} & $110 \sim 129$ & $\begin{array}{l}27 \\
(\text { 全例 } \bigcirc)\end{array}$ & $\begin{array}{l}2 \\
\text { (全例○) }\end{array}$ & 0 & 0 & 29 \\
\hline & $\sim 109$ & $\begin{array}{l}65 \\
(\text { 全例 } \bigcirc)\end{array}$ & $\begin{array}{l}5 \\
(\text { 全例 } \bigcirc)\end{array}$ & 0 & 0 & 70 \\
\hline & 計 & $\begin{array}{l}102 \\
\text { (全例 } \bigcirc)\end{array}$ & 11 & 17 & 22 & 152 \\
\hline
\end{tabular}

的実験から，著者らの開発した自動尿糖測定便 器は，尿糖発見に極めて高い有用性のあること が判明した。

本多記念病院を訪れた 2 力月間の患者, 152 人について無選択に各年踚層にわたり検尿し尿 糖試験紙と本装置測定結果を比較した。試験紙 で陰性であっても本装置で糖が検出されたもの は26例（17.1\%）みられた。しかもこれらの症 例はいずれも血糖值は高く，すでに糖疗病の診 断がついていた。本法陰性のものは全例試験紙 陰性であり，これらの血糖值は正常範囲内であ った．試験紙陽性例はいずれも本法陽性であり， これらの症例はいずれも血糖值が高值を示し， 糖尿病の診断がついていた.

血糖值 $150[\mathrm{mg} / \mathrm{d} l]$ 以上の 34 症例は本装置 による検査では全例陽性であった，34例中血糖 值 $200[\mathrm{mg} / \mathrm{d} l]$ 以上の 1 例（本装置 $50 \sim 99$ $[\mathrm{mg} / \mathrm{d} l], 150 \sim 200[\mathrm{mg} / \mathrm{d} l]$ の 2 例（同 $0 \sim 49$ $[\mathrm{mg} / \mathrm{d} l])$ および 8 例（同 $50 \sim 99[\mathrm{mg} / \mathrm{d} l]$ )
は試験紙陰性であった。これら34例はいずれも 薬物療法を行っている糖尿病患者であった。こ のことから幅広い検出濃度範囲を持つものの低 濃度尿糖を検出しない試験紙に比較し，本装置 は低濃度にも感知することが判った。

血糖値 $130 \sim 149[\mathrm{mg} / \mathrm{d} l]$ の19例汢本装置陰 性 10例（52\%），本装置陽性 9 例（48\%）であ り，これら9例中 8 例は試験紙陰性，1例のみ 試験紙陽性であった．血糖值130１49[mg/d $l]$ は本法，試験紙共に陽性，陰性相半ばしている が，本法陽性例は糖尿病の診断がつけられてい ることから，本法陽性であれば精密検査を必要 とすると考えられた。

血糖值 $129[\mathrm{mg} / \mathrm{d} l]$ 以下の症例のほとんど は本法，および試験紙陰性であり，糖尿病の診 断もないので本法陰性のときは糖尿病はないも のと考えて差し支えないと思われた.

これら臨床成績からみれば本便器にて尿糖が 検出された時には糖尿病の疑いが濃厚であり， 
したがってその早期発見に有効である.加えて， 排尿前の経口摂取した物を吟味し，再び試験す ることも容易であり，家庭内に設置すれば随時 検査出来, その有用度も極めて高い。

\section{6. 検 討}

試作した自動尿糖測定便器 (XDC-86 SK) は 基礎的検討および実用試験を行った結果，日常
的な尿糖チェックのスクリーニングに非常に有 効であることを確認した。

参 考 文 献

1) A. H. Kadish and D. A. Hall ; A new method for the continuous monitoring of blood glucose by measurement of dissolved oxygen. : Clin. Chem. 11, 869 (1965) 